\title{
Sequential study of liver biopsy in thalassaemia
}

\author{
G MASERA, G JEAN, V CONTER, S TERZOLI, R A MAURI, AND M CAZZANIGA \\ Clinica Pediatrica dell'Università degli Studi, and Laboratorio Istologia Patologia degli ICP, Milan, Italy
}

SUMMARY Liver biopsies were performed in 47 thalassaemic children. 33 of them had laboratory findings that suggested chronic hepatitis; the other 14 patients, without such signs, underwent liver biopsies during splenectomy. Nine patients showed a more or less pronounced fibrosis, 26 showed chronic persistent hepatitis, and 12 had histological evidence of chronic aggressive hepatitis. The last 12 patients who had been treated with corticosteroids, and 9 other patients who showed a worsening of their liver function tests, underwent sequential biopsy. We suggest that chronic liver disease in thalassaemic children can produce inflammatory infiltration even without biochemical or clinical sign of chronic hepatitis, that it can progress towards cirrhosis even in patients with chronic persistent hepatitis, and that there appears to be no benefit in giving corticosteroids.

We have previously reported our experience with thalassaemic liver disease and we pointed out that, in addition to iron overload, the basic liver lesion was caused by the presence of chronic hepatitis. ${ }^{1}$ Later we studied a larger number of patients, including some with no sign of chronic hepatitis in whom surgical biopsies were performed during splenectomy. Patients with chronic aggressive hepatitis (CAH) had been treated with corticosteroids. These patients and those who showed a worsening in their liver function tests underwent sequential biopsy. The aim of this paper is to present all the data obtained during the last 6 years on the development of liver damage and its histology in these patients.

\section{Material and methods}

110 children with $\beta$-thalassaemia aged between 1 and 15 years were studied. 90 of them were treated with transfusions and intramuscular desferrioxamine; they were described previously. ${ }^{1}$ Needle liver biopsy was performed using Menghini's technique in 33 patients, including 26 patients already reported, ${ }^{1}$ who for more than 6 months had been showing serum transaminase values that were at least twice the normal maximum value. In 14 other patients in whom biochemical data were not abnormal, a surgical biopsy was performed during splenectomy. Two pathologists read the slides independently, without knowledge of the clinical data. Later, the two reports were compared together with all the clinical and laboratory data.

The following patients underwent sequential control biopsies at 6-month or 2-year intervals: Patients $(n=12)$ in whom there was histological evidence of $\mathrm{CAH}$; they were treated with betametasone $(0.1 \mathrm{mg} / \mathrm{kg}$ per day for 1 month and then $0.05 / \mathrm{mg}$ per day). Treatment with corticosteroids

Table 1 Histological findings of liver biopsies of children suspected as having chronic hepatitis compared with biopsies of children with normal liver tests

\begin{tabular}{|c|c|c|c|c|c|c|c|c|}
\hline & \multicolumn{4}{|c|}{ Biopsies for suspected chronic hepatitis } & \multicolumn{4}{|c|}{ Biopsies on splenectomy } \\
\hline & $\mathrm{HB}_{\mathrm{s}} \mathrm{Ag}$-positive & $H B_{s} A g$-negative & Total & $\begin{array}{l}\text { Previous acute } \\
\text { icteric hepatitis }\end{array}$ & $H B_{s} A g-p o s i t i v e$ & $\mathrm{HB}_{s} \mathrm{Ag}$-negative & Total & $\begin{array}{l}\text { Previous acute } \\
\text { icteric hepatitis }\end{array}$ \\
\hline \multicolumn{9}{|c|}{$\begin{array}{l}\text { Chronic } \\
\text { persistent } \\
\text { hepatitis } \quad 4\end{array}$} \\
\hline $\begin{array}{l}\text { hepatitis } \\
\text { Chronic } \\
\text { aggressive }\end{array}$ & 4 & 14 & 18 & 1 & 1 & 7 & 8 & 2 \\
\hline hepatitis & $2 *$ & 9 & 11 & 2 & 0 & 1 & 1 & \\
\hline Fibrosis & 1 & 3 & 4 & & 0 & 5 & 5 & \\
\hline Total & 7 & $26+$ & 33 & 3 & 1 & $13 \ddagger$ & 14 & 2 \\
\hline
\end{tabular}

*One patients is still $\mathrm{HB}_{\mathrm{s}} \mathrm{Ag}$-positive after 6 years, $\uparrow 15$ patients are positive for anti-HBsAg, $¥ 2$ patients are positive for anti-HBs $\mathrm{Ag}$. 
Table 2 Results of biopsies in 21 children

\begin{tabular}{|c|c|c|c|c|c|c|c|c|c|c|c|}
\hline \multirow[t]{2}{*}{ Case } & \multicolumn{2}{|l|}{ First biopsy } & \multicolumn{2}{|l|}{ Last biopsy } & \multirow{2}{*}{$\begin{array}{l}H B_{\mathrm{S}} A g \text { still } \\
\text { positive }\end{array}$} & \multirow{2}{*}{$\begin{array}{l}\text { Anti-HBs } A g \\
\text { stillpositive }\end{array}$} & \multirow{2}{*}{$\begin{array}{l}\text { Icteric } \\
\text { hepatitis }\end{array}$} & \multirow[t]{2}{*}{ Splenectomy } & \multirow{2}{*}{$\begin{array}{l}\text { Units of } \\
\text { blood } \\
\text { transfused* }\end{array}$} & \multirow{2}{*}{$\begin{array}{l}\text { Haemoglobin } \\
(\mathrm{g} / 100 \mathrm{ml}) \dagger\end{array}$} & \multirow{2}{*}{$\begin{array}{l}\text { Serum iron } \\
(\mu \mathrm{g} / 100 \mathrm{ml})\end{array}$} \\
\hline & Diagnosis & Age & Diagnosis & Age & & & & & & & \\
\hline 1 & CAH & $4 y 8 m$ & $\underset{\text { cirrhosis }}{\text { CAH }}$ & $9 y 4 m$ & Yes, 4 y $2 \mathrm{~m}$ & No & Yes,3y 6m & Yes, $3 y$ & 99 & $9 \cdot 1$ & 201 \\
\hline $\begin{array}{l}2 \\
3\end{array}$ & $\begin{array}{l}\text { CAH } \\
\text { CAH }\end{array}$ & $\begin{array}{l}9 \mathrm{y} 4 \mathrm{~m} \\
10 \mathrm{y} 11 \mathrm{~m}\end{array}$ & $\begin{array}{l}\text { CPH } \\
\text { CAH } \\
\text { cirrhosis }\end{array}$ & $\begin{array}{l}11 \mathrm{y} 8 \mathrm{~m} \\
15 \mathrm{y}\end{array}$ & $\begin{array}{l}\text { No } \\
\text { No }\end{array}$ & $\begin{array}{l}\text { Yes,8y } 9 \mathrm{~m} \\
\text { Yes, } 12 \mathrm{y} 6 \mathrm{~m}\end{array}$ & $\begin{array}{l}\text { No } \\
\text { No }\end{array}$ & $\begin{array}{l}\text { Yes,3y } \\
\text { Yes, 18m }\end{array}$ & $\begin{array}{r}94 \\
202\end{array}$ & $\begin{array}{l}8.7 \\
8.9\end{array}$ & $\begin{array}{l}230 \\
193\end{array}$ \\
\hline $\begin{array}{l}4 \\
5\end{array}$ & $\begin{array}{l}\text { CAH } \\
\text { CAH }\end{array}$ & $\begin{array}{l}6 y 5 m \\
9 y 8 m\end{array}$ & $\begin{array}{l}\text { CPH } \\
\text { CAH } \\
\text { cirrhosis }\end{array}$ & $\begin{array}{l}8 \mathrm{y} 3 \mathrm{~m} \\
13 \mathrm{y} 8 \mathrm{~m}\end{array}$ & $\begin{array}{l}\text { No } \\
\text { No }\end{array}$ & $\begin{array}{l}\text { No } \\
\text { No }\end{array}$ & $\begin{array}{l}\text { No } \\
\text { Yes,3y } 8 \mathrm{~m}\end{array}$ & $\begin{array}{l}\text { Yes,2y } \\
\text { Yes,5y }\end{array}$ & $\begin{array}{l}111 \\
185\end{array}$ & $\begin{array}{l}8 \cdot 8 \\
9\end{array}$ & $\begin{array}{r}91 \\
302\end{array}$ \\
\hline 6 & CAH & $3 y 9 m$ & Fibrosis & $5 y 7 \mathrm{~m}$ & Yes, 5 y $11 \mathrm{~m}$ & No & No & Yes, 3y & 75 & 8.9 & 200 \\
\hline 7 & CAH & 9 y $5 \mathrm{~m}$ & CPH & 11 y $5 \mathrm{~m}$ & No & Yes,9y 6m & $\mathbf{N}$ & $\mathbf{Y e}$ & 105 & $8 \cdot 8$ & 172 \\
\hline 8 & CAH & $8 \mathrm{y} 3 \mathrm{~m}$ & CPH & $9 \mathrm{y} 11 \mathrm{~m}$ & No & Yes, $7 y$ 4m & No & Yes,8y $7 \mathrm{~m}$ & 105 & 8.9 & 180 \\
\hline 9 & CAH & $7 \mathrm{y} 11 \mathrm{~m}$ & Fibrosis & $10 \mathrm{y} 8 \mathrm{~m}$ & No & No & No & Yes,3y & 117 & 8.9 & 200 \\
\hline 10 & CAH & 6 y $8 \mathrm{~m}$ & Fibrosis & $7 \mathrm{y} 6 \mathrm{~m}$ & No & No & No & Yes, $17 \mathrm{~m}$ & 90 & $10 \cdot 3$ & 170 \\
\hline 11 & CAH & $8 \mathrm{y} 10 \mathrm{~m}$ & Fibrosis & $9 y 5 \mathrm{~m}$ & No & Yes,9y 3m & No & Yes,3y 6m & 92 & $8 \cdot 9$ & 200 \\
\hline 12 & CAH & $9 y 1 \mathrm{~m}$ & Cirrhosis & $10 \mathrm{y} 10 \mathrm{~m}$ & No & No & No & Yes,7y $11 \mathrm{~m}$ & 107 & 9.1 & 184 \\
\hline 13 & CPH & $10 \mathrm{y} 1 \mathrm{~m}$ & CPH & $15 \mathrm{y} 5 \mathrm{~m}$ & No & Yes, 12 y $3 \mathrm{~m}$ & No & Yes,2y & 214 & 9.1 & 183 \\
\hline 14 & CPH & $13 \mathrm{y} 4 \mathrm{~m}$ & Cirrhosis & $16 \mathrm{y} 4 \mathrm{~m}$ & No & Yes, $13 \mathrm{y} 3 \mathrm{~m}$ & No & Yes, 3y & 222 & 9 & 210 \\
\hline 15 & CPH & $4 y 3 m$ & Fibrosis & $6 y 11 \mathrm{~m}$ & No & Yes, 5 y $3 \mathrm{~m}$ & No & Yes,6y $11 \mathrm{~m}$ & 73 & 8.9 & 108 \\
\hline 16 & CPH & 7 y $7 \mathrm{~m}$ & Fibrosis & $9 \mathrm{y} 10 \mathrm{~m}$ & No & Yes, 8 y $5 \mathrm{~m}$ & No & Yes, $9 \mathrm{y} 10 \mathrm{~m}$ & 125 & 8.9 & 100 \\
\hline 17 & CPH & $13 y 9 m$ & Cirrhosis & $16 y 7 \mathrm{~m}$ & No & No & No & Yes,4y & 217 & 9 & 135 \\
\hline 18 & CPH & $9 \mathrm{y} 10 \mathrm{~m}$ & CPH & & No & Yes, $7 y$ 11m & No & Yes,6y & 154 & 9.4 & 125 \\
\hline 19 & CPH & $4 y 11 \mathrm{~m}$ & CPH & $6 y 7 \mathrm{~m}$ & No & & Yes, 3y & Yes,4y $11 \mathrm{~m}$ & 76 & $10 \cdot 2$ & 150 \\
\hline 20 & CPH & $12 \mathrm{y} 2 \mathrm{~m}$ & Fibrosis & $13 \mathrm{y} 1 \mathrm{~m}$ & No & Yes, 12 y $6 \mathrm{~m}$ & & Yes, $6 \mathrm{~m}$ & 178 & 9.2 & 190 \\
\hline 21 & Fibrosis & $4 y 9 m$ & CPH & $6 y 3 \mathrm{~m}$ & No & Yes, 3y $6 \mathrm{~m}$ & No & No & 72 & 9.3 & 57 \\
\hline
\end{tabular}

*Total number of units $(300 \mathrm{ml})$ of blood transfused until the last liver biopsy. †Mean haemoglobin during the time between the first and last liver biopsy. $¥$ Mean serum iron during the time between the first and last liver biopsy.

was stopped when inflammatory infiltration disappeared and no piecemeal necrosis could be shown. Patients $(n=9)$ who had no evidence of CAH in the first biopsy, and who later developed symptoms which, on clinical and laboratory data, suggested worsening of liver disease.

\section{Results}

In Table 1 the histological findings of liver biopsies of children suspected to have chronic hepatitis are compared with surgical biopsies obtained during splenectomy in children with normal liver tests. Many of the thalassaemic children, who had had multiple transfusions, showed histological evidence of chronic persistent hepatitis $(\mathrm{CPH})$ or $\mathrm{CAH}$, as reported previously. ${ }^{1}$

Many of these children were infected by hepatitis $B$ virus as shown by the presence of $\mathrm{HB}_{\mathrm{s}} \mathrm{Ag}$ (Table 1 ) and $\mathrm{HB}_{\mathrm{s}} \mathrm{Ab}$ in their blood. We also noticed that of 33 children who underwent liver biopsies and in whom chronic hepatitis was suspected, 18 showed $\mathrm{CPH}, 11$ showed $\mathrm{CAH}$, and 4 showed a more or less pronounced hepatic fibrosis.

Of 14 patients without biochemical signs of liver damage who underwent surgical biopsies during splenectomy 8 had $\mathrm{CPH}, 1$ had $\mathrm{CAH}$, and 5 showed a more or less pronounced fibrosis with slight inflammatory infiltration.

21 patients underwent sequential biopsies after a period of between 6 months and 5 years (Table 2, Figure). 12 with CAH were treated with betametasone. Four of them had evidence of $\mathrm{CPH}, 4$ had liver fibrosis, and 4 had macromicronodular cirrhosis: 3 of the last group with cirrhosis also showed persistence of CAH.

Eight children with CPH not treated with corticosteroids showed a reduction in inflammation: 5 patients ( 2 of whom had cirrhosis) and 3 patients with $\mathrm{CPH}$.

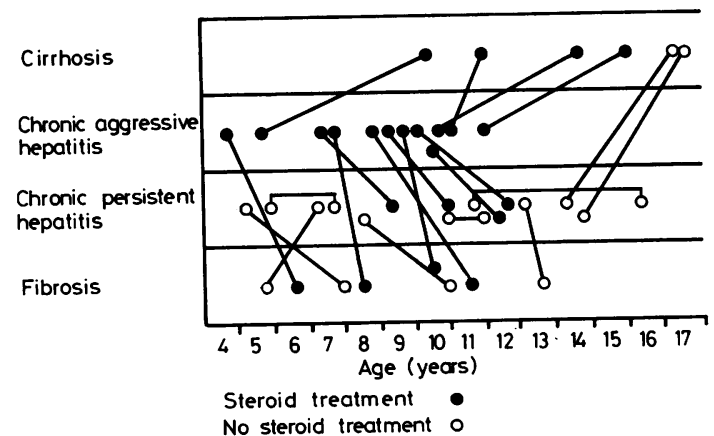

Figure Histological development of the hepatic involvement in 21 thalassaemic patients. In 6 patients the second biopsy showed a cirrhotic pattern, while as a result of the first biopsy 4 children were diagnosed as having chronic aggressive hepatitis and the remaining 2 (the oldest ones) as having chronic persistent hepatitis. 
One patient with hepatic fibrosis without hepatitis showed an increase in inflammatory cells in the portal spaces and fibrous tissue, suggesting a diagnosis of $\mathrm{CPH}$. We found that the normal liver tests, including serum transaminases, did not indicate the inflammatory development of the lesions, even in patients being treated wth corticosteroids.

\section{Discussion}

Our review of hepatic biopsies showed that a large number of transfused thalassaemic children, either $\mathrm{HB}_{\mathrm{s}} \mathrm{Ag}$-positive or negative, with chronic hepatitis, had one of the more common types-CPH or CAH (38 of 104 patients). This observation has not been confirmed in other countries, perhaps because the incidence of hepatitis in Italy is high. ${ }^{2}$ In Milan district for instance, the frequency of $\mathrm{HB}_{\mathbf{s}} \mathrm{Ag}$-positive blood donors is particularly high $(3 \cdot 2 \%$ or 300 times higher than in New York City) (AVIS-Italian Association of Blood Donors-Section of Milan, unpublished data). ${ }^{3-4}$ Moreover the number of children with chronic hepatitis is probably still higher, for we performed liver biopsies only in children who had had high serum transaminases for between 6 months and one year.

We found histological evidence of CPH (8 of 14) and CAH (1 of 14) even in totally asymptomatic patients, with normal standard tests of liver function, who underwent liver biopsy during splenectomy. The characteristics of chronic hepatitis in thalassaemic patients did not differ from those in other transfused patients, such as haemophiliacs, but the course of the disease might have been different from that of the common forms. ${ }^{5}$ Repeated biopsies showed cirrhosis $\mathbf{3}$ or $\mathbf{4}$ years later in $\mathbf{2}$ of $\mathbf{8}$ thalassaemic children who had CPH at their first biopsies.

No clear benefit from corticosteroids in preventing cirrhosis has been proved. In fact in 9 of 12 patients with CAH treated with betametasone there was a reduction of inflammatory activity with dis- appearance of piecemeal necrosis. In one of these patients, and in 3 others, liver specimens showed cirrhosis 2 to 4 years after the first biopsy. The age of the patients in the two groups was similar; therefore it seems that in thalassaemic children chronic hepatitis, either persistent or aggressive, shows progression towards cirrhosis even though the inflammatory activity is reduced by treatment with corticosteroids.

In conclusion, the chronic liver disease of thalassaemic children is characterised by inflammatory infiltration (similar to CAH or $\mathrm{CPH}$ ) even if there is no biochemical or clinical sign of chronic hepatitis, and by progression towards cirrhosis even in cases showing a CPH aspect. There is no clear evidence that treatment with corticosteroids slows this process, though it reduces the inflammation.

Better chelation therapy should improve the prognosis of these children and the method of continuous infusion of desferrioxamine is promising.

\section{References}

1 Masera G, Jean G, Gazzola G, Novakova M. Role of chronic hepatitis in development of thalassaemic liver disease. Arch Dis Child 1976; 51 : 680-6.

2 Coltorti M, Lucchelli P E. Patologia cronica del fegato in Italia-Inchiesta retrospettiva multicentrica. Recent Prog $\operatorname{Med}$ (Roma) 1977; 63: 447-70.

3 Carreri V, Baratta A. Considerazioni sull'andameto epidemiologico delle malattie infettive in Lombardia (1974, 1975, 1976). Epidemiologia e Prevenzione 1977; 1 : 46-52.

4 Ringertz 0 . Epidemiology of serum hepatitis. Clin Gastroenterol 1974; 3: 305-16.

5 Alagille D. L'hepatite chronique active chez l'enfant. Arch Fr Pediatr 1974; 31 : 637-40.

Correspondence to Professor G Masera, Clinica Pediatrica G e D De Marchi, Dell' Universita di Milano, Via Commenda 9, 20122 Milano, Italy.

Received 4 September 1979 